\title{
IgG4-related autoimmune pancreatitis complicated by splenic artery pseudoaneurysm
}

\author{
Hiroshi Sawachika, Shunichi Fujita, Tomoyuki Mukai, Yoshitaka Morita
}

Department of Rheumatology, Kawasaki Medical School, Kurashiki, Japan

Correspondence to Dr Yoshitaka Morita, morita@med.kawasaki-m.ac.jp

Accepted 20 February 2018

\section{DESCRIPTION}

A 65-year-old man presented with a 1-year history of swelling of the submandibular salivary glands bilaterally. Blood tests revealed C-reactive protein (CRP) level of $0.28 \mathrm{mg} / \mathrm{L}$, leucocyte count of $5.22 \times 10^{9} / \mathrm{L}$ (neutrophil count $3.07 \times 10^{9} / \mathrm{L}$ ), haemoglobin level of $13.1 \mathrm{~g} / \mathrm{dL}$ and platelet count of $234 \times 10^{9} / \mathrm{L}$. Serum IgG and IgG4 levels were $2054 \mathrm{mg} / \mathrm{dL}$ (normal 861-1747) and $540 \mathrm{mg} / \mathrm{dL}$ (4.8-105), respectively. Biopsy of the right submandibular gland revealed a dense lymphoplasmacytic infiltrate and storiform fibrosis with increased IgG4-positive plasma cells (IgG4:IgG ratio 67\%). Contrast-enhanced CT (CE-CT), which was performed to evaluate other sites of involvement, showed diffuse enlargement of the pancreas with a capsule-like rim (figure 1A). A diagnosis of IgG4-related sialadenitis and autoimmune pancreatitis was
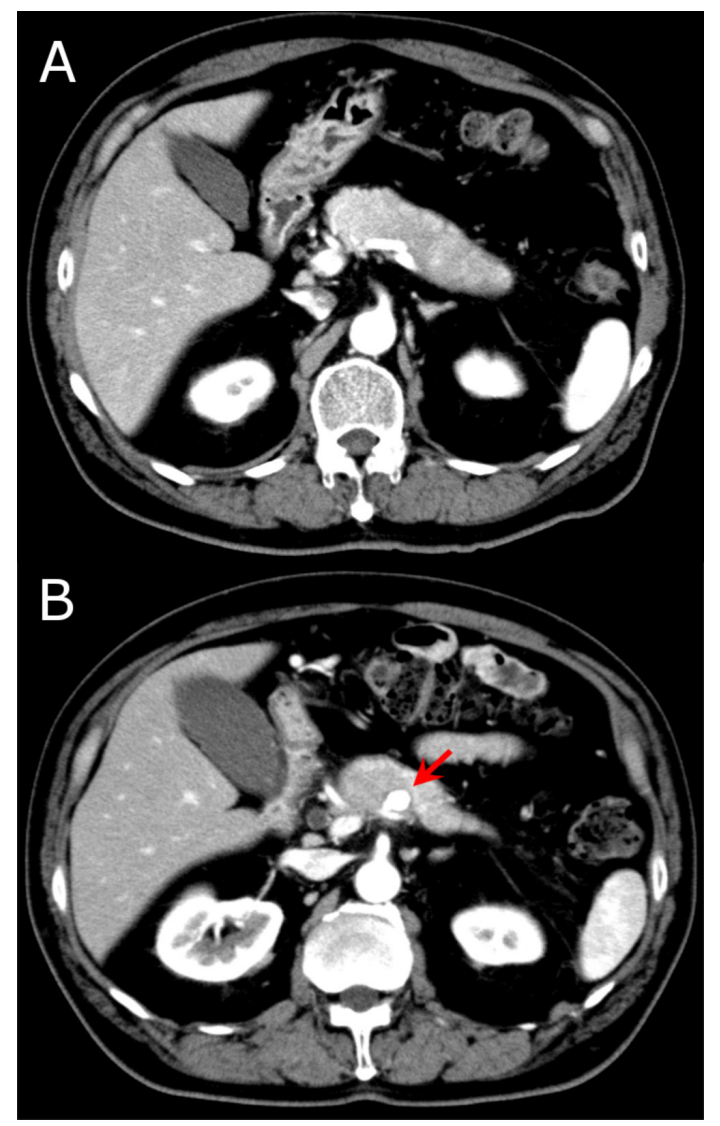

Figure 1 Contrast-enhanced CT on presentation (A) and after 1 year of observation (B) showing diffuse enlargement of the pancreas. A splenic artery pseudoaneurysm (red arrow, $11 \mathrm{~mm}$ in diameter) was newly formed at 1-year follow-up (B). made. The patient had no abdominal complaints or jaundice, and he was followed up with careful observation.

One year later, follow-up CE-CT identified a newly formed aneurysm (11 $\mathrm{mm}$ in diameter) of the splenic artery (figure 1B). No other vascular abnormalities were identified on CE-CT. Laboratory tests showed serum CRP of $0.21 \mathrm{mg} / \mathrm{L}$ and amylase of $38 \mathrm{U} / \mathrm{L}$ (normal 44-132). Liver function tests were normal. Serum IgG4 level was unchanged at $472 \mathrm{mg} / \mathrm{dL}$. We considered that the newly formed aneurysm was likely to be a pseudoaneurysm due to autoimmune pancreatitis. Coil embolisation was then performed to prevent rupture of this pseudoaneurysm, and the patient was started on prednisolone $70 \mathrm{mg} /$ day $(1 \mathrm{mg} / \mathrm{kg})$ to control the activity of autoimmune pancreatitis. He responded favourably to the corticosteroid treatment, and 1 week later the pancreatic enlargement showed some reduction in size on CE-CT. The patient received $70 \mathrm{mg}$ /day of prednisolone for 1 week, followed by $40 \mathrm{mg} /$ day for 2 weeks, $30 \mathrm{mg} /$ day for 3 weeks, and thereafter the drug was gradually tapered.

Arterial pseudoaneurysm complicating acute or chronic pancreatitis is well recognised, and the splenic artery is the most commonly affected vessel. ${ }^{1}$ However, as far as we can establish from a search of the literature, there are no published reports of autoimmune pancreatitis with associated splenic artery pseudoaneurysm. Thus, splenic artery pseudoaneurysm should be recognised as a potentially fatal complication of autoimmune pancreatitis. CE-CT could be the imaging modality of choice in the evaluation of abnormalities of splenic vasculature in this disease.

\section{Patient's perspective}

"I am relieved that the aneurysm was identified before rupture. I appreciate my doctor's appropriate treatment."

\section{Learning points}

Splenic artery pseudoaneurysm should be recognised as a potentially fatal complication of autoimmune pancreatitis.

- Contrast-enhanced CT could be the imaging modality of choice in the evaluation of abnormalities of splenic vasculature in autoimmune pancreatitis. 


\section{Images in...}

Contributors HS, SF and YM were involved in conception or design of the work. HS was responsible for acquisition of data. HS, SF, TM and YM were responsible for analysis and interpretation of data. HS, SF, TM and YM drafted or revised the manuscript.

Funding This research received no specific grant from any funding agency in the public, commercial or not-for-profit sectors.

Competing interests None declared.

Patient consent Obtained.
Provenance and peer review Not commissioned; externally peer reviewed.

(C) BMJ Publishing Group Ltd (unless otherwise stated in the text of the article) 2018. All rights reserved. No commercial use is permitted unless otherwise expressly granted.

\section{REFERENCE}

1 Verde F, Fishman EK, Johnson PT. Arterial pseudoaneurysms complicating pancreatitis: literature review. J Comput Assist Tomogr 2015;39:7-12.

Copyright 2018 BMJ Publishing Group. All rights reserved. For permission to reuse any of this content visit http://group.bmj.com/group/rights-licensing/permissions.

BMJ Case Report Fellows may re-use this article for personal use and teaching without any further permission.

Become a Fellow of BMJ Case Reports today and you can:

- Submit as many cases as you like

- Enjoy fast sympathetic peer review and rapid publication of accepted articles

Access all the published articles

Re-use any of the published material for personal use and teaching without further permission

For information on Institutional Fellowships contact consortiasales@bmjgroup.com

Visit casereports.bmj.com for more articles like this and to become a Fellow 